\title{
ВІКОВІ ТА ГЕНДЕРНІ АСПЕКТИ ХРОНІЧНОГО ОБСТРУКТИВНОГО ЗАХВОРЮВАННЯ ЛЕГЕНЬ
}

\author{
Х. Я. Максів, Г. О. Мірошнік, О. П. Мялюк, М. І. Марущак, М. С. Люблінська \\ Двнз «Тернопільський державний медичний університет \\ імені І. Я. Горбачевського МОЗ Украӥни" \\ Рівненський державний базовий медичний коледж
}

\begin{abstract}
У статті проаналізовано частоту захворюваності на хронічне обструктивне захворювання легень серед осіб чоловічої та жіночої статі, а також встановлено вікові періоди з найбільшим ризиком розвитку даної патології. Аналіз літературних джерел вказує на те, що хронічне обструктивне захворювання легень частіше розвивається в чоловіків, проте в останнє десятиріччя поширеність даної патології значно зросла і серед жінок. Зазначено, що хронічне обструктивне захворювання легень розвивається у різні вікові періоди, тому методи профілактики повинні спрямовуватися як на дітей, так і на дорослих та осіб похилого віку.
\end{abstract}

\section{AGE AND GENDER ASPECTS OF CHRONIC OBSTRUCTIVE PULMONARY DISEASE}

\author{
H. Ya. Maksiv, H. O. Miroshnik, O. P. Mialiuk, M. I. Marushchak, \\ M. S. Liublinska
}

\section{Horbachevsky Ternopil State Medical University Rivne Medical College}

\begin{abstract}
The article analyzes the incidence of chronic obstructive pulmonary disease among males and females, as well as establishes age periods with the greatest risk of development of this pathology. Analysis of research articles suggests that chronic obstructive pulmonary disease often develops in men, but in the last decade, the prevalence of this pathology has increased significantly among women. It is noted that chronic obstructive pulmonary disease develops at different ages, so prophylaxis should be directed at both children and adults, and the elderly.
\end{abstract}

Вступ. Хронічні обструктивні захворювання легень (ХОЗЛ) стрімко зростаюча в світі проблема. Fabbri i Rabe запропонували розглядати ХОЗЛ як «хронічний системний запальний синдром» [1]. Згідно з даними ВОО3, до 2020 р. ця патологія займе п'яте місце серед найпоширеніших хвороб у світі, а також третє місце серед причин смертності [2, 3]. В останні роки все ширше обговорюють системні ефекти ХОЗЛ, що можуть обтяжувати перебіг захворювання в окремих хворих і $\epsilon$ важливою ланкою «причинного патогенетичного кола» [4-6]. На різних стадіях ХОЗЛ вірогідність виникнення подібних реакцій різна й з прогресуванням хвороби частота їх поєднаного перебігу зростає. У пацієнтів спостерігають ендокринні дисфункції, розлади периферичного кровообігу, порушення моделювання кісткової тканини [7].

Мета дослідження: проаналізувати частоту захворюваності на ХОзЛ серед осіб чоловічої та жіночої статі, а також встановити вікові періоди з найбільшим ризиком розвитку даної патології.

Основна частина. Офіційна статистика поширеності бронхообструктивної патології, за даними Глобальної ініціативи з ХОЗЛ (GOLD), свідчить про те, що в країнах, які знаходяться на різних континентах (США, Австрія, Німеччина, Ісландія, Австралія), захворюваність на ХОЗЛ у жінок вища, ніж у чоловіків. Тяжкість перебігу й прогноз хвороби зумовлені екстрапульмональними процесами, у тому числі супутніми захворюваннями і різними шкідливими чинниками [8, 9]. Дослідження, проведені у 1996 р. під керівництвом Всесвітньої організації охорони здоров'я (ВООЗ) і Світового банку розвитку урядових і неурядових організацій охорони здоров'я, встановили середній рівень поширеності ХОЗЛ - 9,34 на 1000 серед чоловіків і 7,33 на 1000 серед жінок. Однак результати останніх досліджень в європейських країнах свідчать про те,

(с) Х. Я. Максів, Г. О. Мірошнік, О. П. Мялюк, М. І. Марущак, М. С. Люблінська, 2017

10 ISSN 2411-1597. МЕДСЕСТРИНСТВО. 2017. № 3 
що в регіонах із дуже високою частотою куріння поширеність ХОЗЛ наближається до 80-100 на 1000 населення. У середньому щорічно на кожні 30-45 випадків ХОЗЛ виявляють 5-7 нових. На думку експертів ВООЗ, у світі налічують близько 210 млн хворих на ХОЗЛ [10]. Крім куріння, спадкових і соціально-економічних факторів, респіраторного ризику зазнає населення, яке проживає в несприятливих екологічних умовах, що працює на виробництві з підвищеним пилоутворенням та токсичністю (металургія, машинобудування, виробництво будматеріалів, текстильна промисловість та ін.). Незважаючи на постійний контроль за дотриманням санітарно-гігієнічних норм на підприємствах, ступінь ризику розвитку ХОЗЛ зберігається на досить високому рівні у зв'язку зі специфікою технологічних ліній [11]. На багатьох підприємствах, де працюють переважно жінки, залишаються незмінними протягом десятиліть несприятливі умови праці, виробнича шкідливість перевищує гранично допустимий рівень.

Раніше поширеність ХОЗЛ була вищою серед чоловіків, порівняно з жінками, що пояснювалося впливом різних факторів ризику. Однак, на даний час у розвинених країнах поширеність хозЛ серед жінок значно зросла [12]. Так, за останнє десятиліття показник збільшився на 69 \%, смертність від ХОЗЛ зросла серед жінок у 15 разів $[13,14]$. Відмінність впливу різних токсичних факторів на жінок і чоловіків можна пояснити по-різному насамперед це анатомо-фізіологічні відмінності. У чоловіків дихальні рухи здійснюються переважно за рахунок роботи діафрагми, а у жінок - міжреберними і грудними м'язами, функціональний резерв яких вже початково менший. Крім того, ужінок вищий ризик розвитку гіперреактивності бронхів під час репродуктивного періоду, коли відбуваються циклічні зміни з боку респіраторного тракту, що дозволяє говорити про особливу роль гормонального фону жінок у розвитку схильності до захворювань системи органів дихання. Вважають, що естрадіол опосередковує свій вплив через зміну концентрації ацетилхоліну, характер секретуючого бронхіального слизу, продукцію простагландинів і щільність b1 - i b2-адренергічних рецепторів у легеневій тканині [15]. Після 30 років починаються процеси вікових змін легень, такі як зменшення еластичності, зниження максимальних експіраторних потоків, наростання залишкових об'ємів. Однак у жінок ці зміни починаються трохи пізніше і прогресують повільніше, ніж у чоловіків. Вважають, що основною причиною настільки виражених відмінностей в анатомії і фізіо- логії респіраторного тракту $\epsilon$ гормональний вплив естрогенів, пролактину і тестостерону. Більше того, в зв'язку з циклічністю гормональної активності ужінок початково визначається більш висока концентрація прозапального інтерлейкіну-8 (IL-8), порівняно з чоловіками. Даний цитокін притягує нейтрофіли в легеневу тканину і розглядається як специфічний біологічний маркер ХОЗЛ. Фактор куріння у жінок спричиняє ще більше наростання рівня IL-8, що призводить до збільшення вмісту нейтрофілів у дихальних шляхах $[16,17]$. Встановлено, що жінки особливо чутливі до патологічної дії як тютюнового диму, так і інших шкідливих факторів. Тривогу викликає зростаюча поширеність тютюнокуріння серед дітей шкільного і особливо підліткового віку. Діти роблять перші спроби закурити у віці 8-10 років [18].

Незважаючи на високі цифри поширеності ХОЗЛ, за даними Європейського респіраторного товариства, тільки 25 \% випадків захворювання діагностують вчасно. Значне число випадків цього захворювання не визначається на ранніх етапах і, на превеликий жаль, хворі на ХОзЛ звертаються за медичною допомогою вже на пізніх стадіях захворювання, коли можливості терапії вкрай обмежені. Особливо тяжко діагностувати захворювання у дітей, які постійно рухаються. Для запобігання появи захворювання у дитячому віці жінкам у період вагітності необхідно вести здоровий спосіб життя, не приймати лікарські препарати без призначення лікаря і стежити за своїм станом здоров'я [19]. Незважаючи на те, що ХОзЛ захворювання "дорослих», існує ряд дитячих пульмонологічних хвороб, які можна розглядати в рамках хОзЛ. Це хвороби, які супроводжуються вираженим, що погано піддаються терапії, тяжким обструктивним синдромом (задуха), при якому порушується провідність бронхів, які набрякають, переповнюються слизом. Внаслідок цього відбувається спазм, який заважає диханню. Клінічна картина абсолютно аналогічна тій, що спостерігається у дорослих пацієнтів із ХОЗЛ, і лікарі діагностують у дитини ХОЗЛ. Бронхіальна астма, бронхолегенева дисплазія мають такі ж прояви, що й ХОЗЛ. Вдихання тютюнового диму з раннього віку загрожує розвитком емфіземи легень. Процес розвивається таким чином: слизова бронхів постійно запалена через токсичний дим. Це призводить до хронічного бронхіту і звуження просвіту бронхів. У результаті повітря важко проникає в легені. Після видиху в порожнинах легень залишається трансформований кисень, який вже не бере участі в диханні, 
але займає багато місця, розтягуючи тканину. Згодом легені втрачають здатність нормально скорочуватися, отримувати кисень і виводити вуглекислий газ. З'являється задишка. Якщо у дошкільному віці відмічається фізіологічна емфізема (лікарі називають ії «вікарна»), то у віці 10-11 років у них вже з'являються ознаки ХОЗЛ. На даний час військові лікарі, оцінюючи стан здоров'я призовників, часто виявляють першу і навіть другу стадію ХОЗЛ. Незважаючи на досягнення в боротьбі з недугою, потрібно намагатися попередити їі в ранньому віці, знижуючи вплив факторів ризику [20]. На форумі міжнародних пульмонологічних спільнот (FIRS) 2010 р. був оголошений роком легеневого здоров'я (Year of The Lung). ВООЗ запропонувала проект «Глобальний альянс проти хронічних респіраторних захворювань» («Global Alliance Against Chronic Respiratory Diseases» - GARD) - це добровільний союз національних і міжнародних організацій, інститутів і установ діючих у напрямку досягнення спільної мети зміцнення респіраторного здоров'я в усьому світі.

Діагноз ХОЗЛ повинен передбачатися при наявності кашлю і виділення мокротиння у всіх пацієнтів із факторами ризику, що спричиняють розвиток ХОЗЛ, з яких головне значення мають фактори навколишнього середовища - куріння, тривалий вплив професійних подразників (пил, хімічні поллютанти, пари кислот і лугів), атмосферне і домашнє забруднення повітря [21]. Складність своєчасної діагностики ХОЗЛ визначається і тим, що пацієнти звертаються до лікаря лише при загостренні вже наявного захворювання, що перебігає з підвищенням температури тіла, посиленням кашлю і продукції мокротиння або задишкою, що заважає роботі, при посиленні її аж до задухи. Нерідко діагностика загострення - це і момент первинного встановлення діагнозу захворювання [22]. На думку Р. Я. Ліхачової, діагностичні

\section{СПИСОК ЛІТЕРАТУРИ}

1. Complex chronic comorbidities of COPD / L. M. Fabbri, F. Luppi, B. Beghé, K. F. Rabe // European Respiratory Journal. 2008. - Vol. 31, № 1. - P. 204-212.

2. Chronic obstructive pulmonary disease surveillance: United States, 1971- 2000 / D. M. Mannino, D. M. Homa, L. J. Akinbami [et al.] // MMWR Surveill. Summ. - 2002. № 6. - P. 1-16.

3. Smoking cessation programs targeted to women: a systematic review / I. Torchalla, C. T. Okoli, J. L. Bottorff [et al.] // Women Health. - 2012. - №. 1. - P. 32-54.

4. Agusti A. G. N. Systemic effects of chronic obstructive pulmonary disease [Text] / A. G. N. Agusti, A. Noguera, J. Sauleda // Eur. Respir. J. - 2003. - Vol. 21. - P. 347-360. помилки допускаються в основному внаслідок неповного обстеження хворих (у 90 \% випадків не проводиться повного обстеження хворих на ХОЗЛ) на амбулаторному етапі, що призводить до подовження діагностичного періоду і зростання економічних збитків [23]. Низька діагностика ХОЗЛ визначається також у пацієнтів у віці старше 60 років. Люди похилого і старечого віку хворіють на ХОЗЛ приблизно в 4-5 разів частіше, ніж молоді особи [24]. Так, у структурі первинної медичної допомоги у Великобританії річна частота консультацій з приводу ХОЗЛ на 10000 населення становить від 417 у віці 4564 роки до 886 у віці 65-75 років, і 1032 у віці 75-84 роки (ці цифри в 2-4 рази перевищують відповідні показники для стенокардії) [25]. Дослідниками показано, що ХОЗЛ $\epsilon$ синдромом прискореного старіння легень [26]. Труднощі діагностики хвороби в осіб похилого віку пов'язані з рядом обставин. Вік супроводжується прогресивним зниженням чутливості до симптомів захворювання, в тому числі респіраторних, що найбільше стосується задишки. Відсутність скарг, малорухливий спосіб життя, зниження активної діяльності в осіб похилого віку призводить до непомітного прогресування ХОЗЛ [27]. ХОЗЛ довгий час може перебігати без виражених клінічних проявів. У цьому випадку зростає роль настороженості лікаря щодо пацієнтів, які курять, та виникає необхідність дослідження легеневої функції у таких пацієнтів навіть без клінічних симптомів [28].

Висновки. 1. Аналіз літературних джерел вказує на те, що хронічне обструктивне захворювання легень частіше розвивається в чоловіків, проте в останнє десятиріччя поширеність даної патології значно зросла і серед жінок.

2. Хронічне обструктивне захворювання легень розвивається у різні вікові періоди, тому методи профілактики повинні спрямовуватися як на дітей, так і на дорослих та осіб похилого віку.

5. Andreassen $\mathrm{H}$. Chronic obstructive pulmonary disease as a systemic disease: an epidemiological perspective [Text] / H. Andreassen, J. Vestbo // Eur. Respir. J. - 2003. Vol. 22(46-suppl). - P. 2-4.

6. Wouters E. F. M. Chronic obstructive pulmonary disease. 5: systemic effects of COPD [Text] / E. F. M. Wouters // Thorax. 2002. - Vol. 57. - P. 1067-1070.

7. Островський М. М. До питання поліморбідності та коморбідності у хворих на ХОЗЛ [Текст] / М. М. Островський, П. Р. Герич // Український пульмонологічний журнал. 2011. - № 4. - C. 19-24.

8. Фещенко Ю. И. Новая редакция глобальной инициативы по ХОЗЛ [Текст] / Ю. И. Фещенко // Український пульмонологічний журнал. - 2012. - № 2. - С. 6-8. 
9. Global Initiative for Chronic Obstructive Lung Disease (GOLD). Global strategy for diagnosis, management, and prevention of chronic obstructive pulmonary disease. NHLBI/WHO workshop report. Last updated 2010 // www. goldcopd.org.

10. Гринштейн Ю. И. Хроническая обструктивная болезнь легких : практическое руководство для врачейкурсантов / Ю. И. Гринштейн. - Красноярск : КрасГМУ, 2009. - 79 c.

11. Антонов Н. С. Хронические обструктивные заболевания легких : диагностика, лечение и профилактика / Н. С. Антонов. - Москва, 2002. - 46 с.

12. Soriano J. B. Chronic obstructive pulmonary disease: a worldwide problem / J. B. Soriano, B. Lamprecht // Med. Clin. North. Am. - 2012. - №. 4. - P. 671-680.

13. Лещенко И. В. Современные проблемы диагностики хронической обструктивной болезни легких / И. В. Лещенко, С. И. Овчаренко // Пульмонология. - 2003. № 4. - С. 160-164.

14. Mannino D. M. Global burden of COPD: risk factors, prevalence, and future trends / D. M. Mannino, A. S. Buist // Lancet. - 2007. - №. 370. - P. 765-773.

15. Cellular and structural bases of chronic obstructive pulmonary disease / M. Saetta, G. Turato, P. Maestrelli [et al.] // Am. J. Respir. Crit. Care. Med. - 2001. - № 163. P. 1304-1309.

16. Stoller J. K. Alpha-1-antitripsin deficiency / J. K. Stoller, L. S. Aboussouan // Lancet. - 2005. - № 365. - P. 2225-2236.

17. Lee P. Emphysema in nonsmokers: alpha 1-antitrypsin deficiency and other causes / P. Lee, T. R. Gildea, J. K. Stoller // Cleve Clin. J. Med. - 2002. - № 69. - P. 928-946.

18. Факторы риска хронической обструктивной болезни легких / Т. В. Ивчик, А. Н. Кокосов, Е. Д. Янчина [и др.] // Пульмонология. - 2003. - № 3. - С. 6-15.
19. Global Strategy for the Diagnosis, Management, and Prevention of Chronic Obstructive Pulmonary Disease (UPDATED 2006) Global Initiative for Chronic Obstructive Lung Disease.

20. Овчаренко С. И. Современные проблемы диагностики хронической обструктивной болезни легких / С. И. Овчаренко, И. В. Лещенко // Русс. медиц. журн. -2003. Т. 11, № 4. - С. 160-163.

21. Овчаренко С. И. Алгоритм лечения больных хроническими обструктивными болезнями легких / С. И. Овчаренко, И. В. Литвинова, И. В. Лещенко // Русс. медиц. журн. - 2004. - Т. 12, № 7. - С. 489-491.

22. Хроническая обструктивная болезнь легких / А. Р. Татарский, С. Л. Бабак, А. В. Кирюхин [и др.] // Consilium medicum. - 2004. - T. 6, № 4. - С. 259-263.

23. Лихачева Р. Я. Состояние амбулаторно-поликлинической помощи больным с заболеваниями органов дыхания / Р. Я. Лихачева, Т. В. Денисова, Л. К. Зеленкова // Пульмонология. - 2004. - № 1. - С. 45-48.

24. Фещенко Ю. И. Проблемы хронических обструктивных заболеваний легких / Ю. И. Фещенко // Український пульмонологічний журнал. - 2002. - № 1. - С. 5-10.

25. British Thoracic Society. Guidelines for the management of COPD // Thorax. - 1997. - Vol. 52. - P. S1-S28.

26. Ito K. COPD as a disease of accelerated lung aging / K. Ito, P. J. Barnes // Chest. - 2009. - Vol. 135, № 1. P. 173-180.

27. Смирнова М. С. Хроническая обструктивная болезнь легких: гериатрические аспекты / М. С. Смирнова, П. А. Воробьева // Клиническая геронтология. - 2005. Т. 11, № 5. - С. 32-42.

28. Овчаренко С. И. Особенности хронической обструктивной болезни легкихуженщин / С. И. Овчаренко, В. А. Капустина // Consilium medicum. - 2009. - T. 11, № 3. - С. 5-13. 